THE RISE AND FALL OF REVOLUTIONARY ENGLAND 


\title{
The Rise and Fall of Revolutionary England
}

\section{An Essay on the Fabrication of Seventeenth-Century History}

\author{
Alastair MacLachlan
}

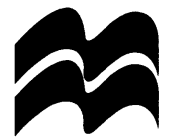


All rights reserved. No reproduction, copy or transmission of this publication may be made without written permission.

No paragraph of this publication may be reproduced, copied or transmitted save with written permission or in accordance with the provisions of the Copyright, Designs and Patents Act 1988, or under the terms of any licence permitting limited copying issued by the Copyright Licensing Agency, 90 Tottenham Court Road, London W1P 9HE.

Any person who does any unauthorized act in relation to this publication may be liable to criminal prosecution and civil claims for damages.

First published 1996 by

MACMILLAN PRESS LTD

Houndmills, Basingstoke, Hampshire RG21 6XS

and London

Companies and representatives

throughout the world

ISBN 978-0-333-62009-0 ISBN 978-1-349-24572-7 (eBook)

DOI 10.1007/978-1-349-24572-7

A catalogue record for this book is available from the British Library.

$\begin{array}{llllllllll}10 & 9 & 8 & 7 & 6 & 5 & 4 & 3 & 2 & 1\end{array}$

$\begin{array}{llllllllll}05 & 04 & 03 & 02 & 01 & 00 & 99 & 98 & 97 & 96\end{array}$

Published in the United States of America 1996 by

ST. MARTIN'S PRESS, INC.,

Scholarly and Reference Division

175 Fifth Avenue, New York, N.Y. 10010 


\section{Contents}

Preface

vii

Introduction

1 The Great Bourgeois Revolutions: A False Genealogy? 7

2 Reclaiming the Revolution

3 Marxist History in a Cold War Era

4 Saving Appearances

5 Levelling out the Revolution

6 Retreating from the Revolution

7 Revolution as Text and Discourse 252

Conclusion: The End of the Line? 298

Notes 326

Index 
England is a perpetual Theatre of revolutions ... in an instant the calm is changed into the most furious tempest, and this tempest changes in a moment into calm.

Eustache Le Noble, Lettres sur l'Angleterre, 1697

One would expect people to remember the past and imagine the future. But in fact, when discoursing or writing about history, they imagine it in terms of their own experience, and when trying to gauge the future they cite supposed analogies from the past: till, by a double process of repetition, they imagine the past and remember the future.

Sir Lewis Namier, 'Symmetry and Repetition', in Conflicts (London, 1942) 


\section{Preface}

During the writing of this book I have been aided by a number of institutions. My thanks to Sydney University and my colleagues in the History Department for an extended absence on an Overseas Study Programme and Long Service leave in 1992 and 1993, and to the directors and secretarial staff of The History of Ideas Unit and the Humanities Research Centre at the Australian National University for placing their resources at my disposal and for providing such an ideal ambience for writing during a significant portion of those years. Likewise, to the Communist Party Archive in North London, the Marx Memorial Library Archive, the Cambridge University Library and the British Library Manuscript Room for allowing access to materials in their possession. To the late Eugene Kamenka and to Alice Tay, and to Pat and Liz Collinson for their hospitality and encouragement in Canberra and Cambridge; to my dear friends, the late Nigel and Marjorie Edgerton, and to my sister and brother-in-law, Sheila and Alan Bracewell, for hospitality and support in London; to John Morrill for some particularly helpful criticism and advice; likewise to Nick Sadington, George Matthews, David Burchall, Jonathan Bordo, Iain MacCalman, Iain Wright, John Mee, John Reeve, Tony Cahill, Stuart MacIntyre, Tony Cousins, and Conal Condren. My thanks also to Meg Miller and to Antony Howe for reading and commenting on my typescript and for removing many errors. A special word of thanks to Vicki for the title; also, for the sharpness and perceptiveness of her criticism, and for goading an incorrigible procrastinator into finishing his work.

My greatest debt, however, is to my research students over the past decade: to Mark Gibson for his work on Anderson, to Alistair Waring for his on the New Left, and, above all, to Antony Howe for his writing and research on Hill (Christopher Hill: A Study of a British Marxist Historian, unpublished M.A. 'Long Essay', Sydney, 1988) and on The Historians' Group of the Communist Party. Chapters 2, 3 and 4 of this book have benefited greatly from his highly critical but not (in my view) unfair examination of Hill's early work in the light of discussions in Soviet historiography 
and the charting of a 'correct line' by the Communist Party of Great Britain.

In 1990 and 1992 Howe conducted extensive interviews and archival work in England for a $\mathrm{PhD}$ (in progress) on the Historians' Group of the Communist Party. As his supervisor over these years, I benefited enormously from discussions with him, and in particular from access to his draft chapters on Marx House, Dona Torr and the origins of the Historians' Group from the 1930s to 1946. He has also allowed me to use his files of research materials and provided me with photocopies from the CP Archive (Historians' Group and Dutt MSS), the Labour Archive at the University of Hull, the Marx Memorial Library Archive, the Morris MSS at University College London, and from Eric Hobsbawm's private papers (more Morris MSS) - my heart-felt thanks. He is, of course, in no way responsible for the judgements expressed in the text. There is one other debt - to the historians themselves. In the pages that follow, I have often been critical of the work of Christopher Hill, Eric Hobsbawm, Lawrence Stone, the late Edward Thompson and Perry Anderson. But even though they might well profoundly disagree with much of the argument of this book, I would like to place on record my appreciation for the stimulus of their writing. 